\title{
BAIT AND VICTIM: A STUDY OF FOOD IN "HANSEL AND GRETEL"
}

\section{ANJUM KHAN}

Assistant Professor, Department of English, Avinashilingam Institute for Home Science and

Higher Education for Women, Coimbatore, Tamil Nadu, India

\begin{abstract}
In this postmodern world of consumerism and capitalist culture, food is an essential instrument of power. It is one of the basic amenities, and this inevitable nature makes it most powerful. On one hand, it controls, and on the other, it cajoles. Palpably, it is used as a bait to allure the needy. Somehow want of food leads to victimization, exploitation, and subordination in the struggle of power. The proposed paper, titled, "Bait and Victim: A Study of Food in Hansel and Gretel" cogitates the power play of food.

KEYWORDS: Food, Victimization, Exploitation \& Subordination
\end{abstract}

Received: Aug 31, 2018; Accepted: Sep 21, 2018; Published: Oct 11, 2018; Paper Id.: IJELDEC20181

\section{INTRODUCTION}

Food is an important trope in children's literature. Kara K. Keeling and Scott T. Pollard agree, "Food is as prevalent and significant in children's literature as it is in literature for any other audience" (3). "Hansel and Gretel" is one of the well-read children's short stories which whirl around food. The present paper is a modest attempt to read food between and beyond the lines in this fairytale. "Hansel and Gretel" is a renowned fairy tale from the collection of Grimm Brothers, 1812. It is believed to be of German origin. Since then, it has been revised, adopted into different forms of art, like, opera, musical, and film. The several parodied and recreated versions have made the original tale more popular. While, it is basically a fairytale for children, it has paved way for myriad of reflections and discourses.

\section{LITERATURE BACKGROUND}

"We never know them well, do we?","Who?","Real people."'What do you mean, 'real people'?"

"As opposed to people in books," Paola explained. "They're the only ones we ever really know well, or know truly... Maybe that's because they're the only ones about whom we get reliable information. . . Narrators never lie."-Donna Leon, A Sea of Troubles

Literature is a translucent reality, rendering every one an open examination. Although, the literature belonging to fantasy genre does not portray reality, it symbolizes it. The underlying theme has moral and social relevance. For this reason, the literature produced for children despite employing paranormal characters and, miraculous dealings, fantasy world appears to be intent on conveying symbolic realities of life.

A literary text is a cultural extension which contains the cultural nuance. Similar to cave painting or a musical composition, it is an archival record of human culture. It preserves memories, traditions, conventions, popular ideas and integrates every aspect of life. It relates to everything ranging from needs to desire and 
insignificance to significance. There are literal, symbolic, figurative depictions in literature that deepen the insight. According to Barton and Hudson, a literary symbol designates "an object or a process that not only serves as an image itself but also refers to a concept or abstract idea that is important to the theme of a work"

The representation of food in literature is perhaps subtle at times; however, it has been recurrent. It is food which qualifies a culture valiant or tame, modern or conventional, and so on. William R. Dalessio remarks, "Just as an item of food signifies an ethnic or "American" cultural identity, the acts performed on these edible signifying units-food preparation and food consumption—signify what these cultures define as feminine or masculine" (13)

Generally speaking, food is sustenance. However, it represents various significant aspects in human life. Food is used to bait, represent power, mastery, exploitation, and plot. The power of food is supreme. John L. Smith praises food, "Without food there is no life" (1). It is believed that food is the root cause for civilisation. Further, it has paved way for political structures, feudal system, government policies and much more in times that followed. Tokomo Aoyama observes:

That food is no simple matter has been widely recognized—in fields such as anthropology, sociology, food science, semiotics, history, political science, and economics, as well as in literary, film, and cultural studies. Food nourishes and poisons; it soothes and tortures, divides as well as unites individuals and groups of people. Food is essential, but it can also be seen as optional, superfluous, or extravagant. Food plays important roles in various types of rituals. It also serves as a means of communicating and acting out our religious, political, philosophical, and cultural views or of expressing a range of emotions. Food may be an object of intense desire, admiration, addiction, craving, fear, disgust, and loathing, or it may be ignored or rejected either intentionally or unintentionally. Food involves production, distribution, preparation, and consumption, and in each process there are rules, taboos, structures, order, customs, styles, fashions, and conventions to create, to follow, or to break. Food has been discovered, invented, classified, and scrutinized, as well as enjoyed, consumed, and devoured (1).

There are several literary works, which include the aspect of food or leastwise refer to food in a subtle way. May it be Earnest Hemming way's The Old Man and the Sea or, Charles Dickens' The Great Expectations or, Maya Angelou's I Know Why the Cage Bird sings, food makes up an important motif. Similarly, there are critical and scholarly discourses on food in literature. Anita Mannur explores Indian diaspora in terms of food habits in her book, titled, Culinary Fictions: Food in South Asian Diasporic Culture. She uses the metaphor of coconut to describe the Indian immigrants in abroad, "Here, the coconut stands in for all that rings stereotypic about Indian Americans: the notion that the community is uniformly flourishing and has made the better of often hostile environments" (2).

\section{THE VICTIMS AND BAITS}

There have been several scholar critics who have revisited and reinterpreted the Grimm's fairytale, "Hansel and Gretel". There have also been interesting books influenced by Hansel and Gretel like, Martin Howard's How to Cook Children: A Grisly Recipe Book published in 2009. Bruno Bettelhe's reading of "Hansel and Gretel" is one of the well-known appraisals. It is cited by many scholars in their academic ventures. Scott Harshbarger examines the dark side of 'narrative transport' in "Hansel and Gretel". He presents a report on the negative impact of this fairytale on the readers. Similarly, Schuman P. Eliot explores the psychological construct of this fairytale. 
The fairytale, "Hansel and Gretel" is a narrative of victims and baits. All the characters in the fairytale, "Hansel and Gretel" are victims of food. The family of the wood cutter fall prey to poverty. Hansel and Gretel are victimized as a result of poverty, lack of love, and lack of food for the witch. The witch is also a victim of hunger. She strives hard to seek food. She designs a cottage to lure food. However, she succeeds in finding food, she is unable to eat and dies starving. The woodcutter is victim of his wife's tyranny and her irrational wishes. On the whole, everyone is victim on account of a reduced amount of food.

The pangs of hunger pave way for great suffering. Hunger is the primary characteristic of poverty and cruelty. It is the driving force in the history of living organisms. Hunger is a physiological condition. The children are hungry and unable to sleep, "The two children were still awake from hunger and heard everything that the mother had said to the father". In addition to be physiological, hunger has psychological effect as well. For instance, hunger changes the heart of the woodcutter. He is persuaded by his second wife to abandon his children as he is intimidated by the dearth of food.

The story "Hansel and Gretel" presents forth poverty in terms of food. The woodcutter is sunk to the depths of poverty as he has no enough bread. His desperation to yield and let go of his children is due to dearth of food. The wood cutter has a house to live in but no food. The step mother offers a meager portion of the bread to the children, "The next morning the mother came and woke them both before sunrise, 'Get up, you children. We are going into the woods. Here is a little piece of bread. Take care and save it until midday"”.

Bread plays an important role in this story. It appears in many forms with several abstract meanings. Bread is the food of the poor. It is also seen as the most basic life-sustaining food. The struggle to provide bread for the children illustrates the family's poverty and quest for basic survival. However, here, in "Hansel and Gretel", it represents love, wealth, bait, and several other aspects.

The story, "Hansel and Gretel" begins with a reference to 'bread' which is a synecdoche for food. Further, the word 'bread' implies wealth and livelihood. The woodcutter is unable to earn bread for his family and as a result he is not able to keep his family together. The opening lines are as follows, "Next to a great forest there lived a poor woodcutter who had come upon such hard times that he could scarcely provide daily bread for his wife and his two children, Hansel and Gretel. Finally he could no longer even manage this, and he did not know where to turn for help."

The word 'bread' also represents strength and masculinity. The woodcutter looses to his wife and as a result, succumbs to her wish. The wife expresses her wish, "One evening as he was lying in bed worrying about his problems, his wife said to him, 'Listen, man, early tomorrow take the two children, give each of them a little piece of bread, then lead them into the middle of thickest part of the woods, make a fire for them, and leave them there, for we can no longer feed them'. "The woodcutter is aware of the fact that leaving his children out in the forest is very perilous. He tries to make his wife understand the repercussions of her whims, "No, woman," said the man, "I cannot bring myself to abandon my own children to wild animals that would quickly tear them to pieces." However, he is unable to dissuade her. He consents to abandon his children in the dangerous forest which is in a way, feeding them to the wild life lurking in the forest.

The children become expendable on grounds of their being small and young. It seems to be so unfair on part of the woodcutter to dessert his children, in order to appease his second wife. The bread, which he brings home or which is baked at home, is a joint effort of everyone in the family, as it is portrayed that the entire family of the woodcutter goes into the forest to gather wood. Perhaps, it is woodcutter who cuts the trees but, nevertheless, the children equally 
participate in the process of gathering wood.

The entire process of deserting the children in the forest is based on the measure of bread available in the poor woodcutter's cottage. The bread is the deciding factor, if the children should live in the house with their parents or they should be sent away. In other words, bread is the matter of life and death for the children, and the availability of bread decides if the children can live or survive. The children live on the basis of daily ration and if the portion declines, they are to be exiled from their house. Once again when the ration goes low, the step mother decides the children should go away:

Not long afterward there was once again no bread in the house, and one evening Hansel and Gretel heard the mother say to the father, "The children found their way back once, and I let it be, but again we have only a half loaf of bread in the house. Tomorrow you must take them deeper into the woods, so they cannot find their way home. Otherwise there will be no help for us".

Bread act as fill for human hunger. Besides being food, the bread serves as guide posts and milestones for the children. Although, the purpose of bread crumbs as guideposts is not served, Hansel completely believes in it. According to Hansel the bread crumbs would guide him and his sister home. He reveres bread as his guide or savior, "Hansel comforted Gretel and said, 'Wait, when the moon comes up I will be able to see the crumbs of bread that I scattered, and they will show us the way back home'".

The power of the bread defeats the faith of the children in God. When, Hansel finds that the door is locked to go out and gather his path finding pebbles, consoles Gretel saying that God will come to their rescue, "Still, he comforted Gretel and said, 'Just go to sleep, Gretel dear. God will help us'”. However, the next day when Hansel Marks his way into forest with the crumbs of bread, he is unable to retrace it as the birds have all eaten. His faith in God is overpowered by the power of food as the birds feed on the bread morsels.

There is mention of berries in the story. Berry is natural food unlike bread which needs baking. It is grown on trees and on shrubs. Hansel and Gretel eat berries when they are very hungry, "They were terribly hungry, for they had eaten only a few small berries that were growing on the ground."The berries symbolize little hope and God's intervention. However, the woodcutter does not consider feeding his family with naturally grown food and instead abandon his children. This appears to be unjust and ruthless.

Firewood is another symbol of food and comfort. It is used as fuel to cook food. The occupation of the woodcutter is closely related to cooking food. The firewood which he and his family cut and gather is used to make fire for cooking or baking. However, it is ironic that the woodcutter gathers wood but has no food to cook. In addition to this; there are small twigs from trees which Hansel and Gretel use to make fire. Unfortunately, this cozy little fire is only a smokescreen that the parents use to put distance between themselves and the children.

Similar to the incidence of victim in the "Hansel and Gretel," there are elements of enticement present in the fairytale. To be precise, there is overpowering presence of bait. The enchanted cottage of the witch is the major symbol of bait. Further, the welcome meal the witch offer is another bait she feeds the children with. Alongside this, the pleasant disguise of the witch while welcoming Hansel and Gretel and their parents talking them into wait in the forest are false pretences to mislead the children. Similarly, there are traps used. The witch's oven and the step mother locking the back door in the night are traps. 
The oven is a trap which the witch uses to ambush Gretel. "Then the old woman called, 'Gretel, come here right now to the oven.' And when Gretel came, she said, "Look inside and see if the bread is nicely brown and done, for my eyes are weak, and I can't see that far. If you can't see that far either, then sit on the board, and I'll push you inside, then you can walk around inside and take a look". At times, the food has a menacing tone in the story. This pitch reverberates in one of the movies, The Visit, based on "Hansel and Gretel" as well. The uncharacteristic grandmother ominously asks, "Is the food okay? I like food".

The house made up of cake and sugar is one of the most important symbols in the short story. There are various interpretations to this symbol. However, here the house literally represents food on one level and bait at another. A house is usually a symbol of comfort and shelter, whereas, here the house primarily represents food. The house is unusual, "On the third day they walked until midday when they came to a little house built entirely from bread with a roof made of cake, and the windows were made of clear sugar". The children are overjoyed and Hansel guides Gretel in eating, "Let's sit down and eat our fill," said Hansel. "I'll eat from the roof, and Gretel, you eat from the window. That will be nice and sweet for you."

Wenying $\mathrm{Xu}$ states, "Although commonplace practices of everyday life, cooking and eating have far-reaching significance in our subject formation" (3). The way one eats is one of the personality traits. The words of Witch are as unusual as the house is. It is rather like a mysterious mantra. She calls out, "Nibble, nibble, little mouse, who is nibbling at my house?". The word 'nibble' for eating demonstrates the power play of words. The children eating the cakes and the sugar are compared to the nibbling mouse. This connotes the children are reduced to rats and their eating to gnawing. Starvation makes them to scramble towards the food and steal it. However, as this house is enchanted, the witch is alerted.

Another bait that the witch throws in the direction of Hansel and Gretel is the welcome meal. She serves food which the children have not eaten in a long time. It is contrast to the small quantity of bread which they use to have. She offers an assortment of delicacies, "Then, she served them a good meal: pancakes with sugar, apples, and nuts; and made two nice beds for them". It is sweet, juicy, and nutritious as well.

Food as an instrument of allure and enchantment: The witch in "Hansel and Gretel" employs food as bait to entice the lost children. She uses food to find her own food. She constructs an enchanted cottage which is made up of cake, sugar and bread. She is overjoyed when she succeeds in ensnaring the children, "She had built her house of bread in order to lure them to her, and if she captured one, she would kill him, cook him, and eat him; and for her that was a day to celebrate. So she was overjoyed that Hansel and Gretel had found their way to her".

In a way, food is glamorous. It makes individuals drool, dream, excite, and anticipate. The life of witch becomes eventful after capturing Hansel and Gretel. The witch salivates over her prospective food. She gazes at Hansel and Gretel and feels contented, "Early the next morning, before they awoke, she got up, went to their beds, and looked at the two of them lying there so peacefully. 'They will be a good mouthful,' she thought" .It is human tendency to look out for the best food. The witch desires to make best of what she has got to eat. She yearns to eat plumpy Hansel. The witch inspects her food and makes sure that she eats the best. Every day, the old woman came and said, "Hansel, stick out your finger, so I can feel if you are fat enough yet".

The predicament of a scapegoat is 'feed the food'. It is fed early, so that it would become succulent food. Likewise, the witch takes upon herself to nourish Hansel and fatten up him. She orders Gretel to cook and feed her brother, 
"Then, she shook Gretel and cried, 'Get up, lazybones! Fetch water. Go into the kitchen and cook something to eat. Your brother is locked in that stall there. I want to fatten him up, and when he is fat I am going to eat him. For now, you have to feed him.' Now Hansel was given the best things to eat every day, so he would get fat, but Gretel received nothing but crayfish shells."

The scene of the witch preparing to eat Hansel and Gretel is grisly and unthinkable. It is appalling. The witch decides to cook Hansel and instructs Gretel to prepare. She becomes very eager, after four weeks, one evening she said to Gretel, "Hurry up and fetch some water. Whether your brother is fat enough now or not, tomorrow I am going to slaughter him and boil him. In the meantime, I want to start the dough that we will bake to go with him." Moreover, she deceitfully allures Gretel into oven so that she would eat both at one go.

The narrative that begins with scarcity of food ends with abundant wealth. Food metamorphosis into treasure. This also implies that food is prosperity. Equating food with treasure also indicates how it is hoarded as it is prized. The witch had concealed the treasure in the house. Although, she had copious wealth, she did not have food. Eventually, Hansel and Gretel find it, "The whole house was filled with precious stones and pearls."

Greediness for food is the hamartia, which brings tragic turning points in the story. The greed of the woodcutter's wife to have the food to her and not share it with her step children results in the exile of the children. Similarly, the greed of food brings lethal luck for Hansel and Gretel when they find the enchanted cottage made up of sweet meat.

One of the morals embedded in the story is that gluttony is wicked. Hansel and Gretel fall prey to the witch because of their greediness for delicious food. They lose themselves in eating the delicacies when they spot the scrumptious cottage made up of cake and sugar. They eat avariciously and fail to hear the witch in disguise of grandmother calling from inside. Therefore, they themselves become the food of the old witch.

\section{CONCLUSIONS}

Food has the power to change reality for individuals. Want of food; lack of food; surplus of food and enough of food - are important paradigms shaping the human condition. Similarly, it can exchange happiness for sadness and vice versa. Good food transforms the bad experience of Hansel and Gretel into excellent one. It transports them to heaven. They do not appear anxious after finding enough food. They feel heavenly, after taking their fill, "Hansel and Gretel went to bed, thinking it was though they were in heaven."

The power of food looms over the plot of "Hansel and Gretel". It is carried through the food chain - from the 'bread crumbs eating birds' to the 'children eating witch.' The power play of food is beyond the control of humans. In fact, it is the food which controls and ensnares living beings. This fundamental nature of food is engrained in many walks of life - like, great philosophies, political systems, social organizations, and so on.

\section{REFERENCES}

1. Aoyama, Tomoko. "Introduction: Why Read Food in Modern Japanese Literature? "Reading Food in Modern Japanese Literature. Honolulu: Hawaii UP, 2008. 1-14. Print.

2. Barton, Edwin J. and Glenda A. Hudson. A contemporary Guide to Literary Terms. Boston: Houghton Mifflin, 1997. 191-93. Print.

3. Brothers, Grimm. “ Hansel and Gretel.” www.boblyman.net Web. Oct. 13, 2015. 
4. Dalessio, William R. Are We What We Eat? FOOD AND IDENTITY IN LATE TWENTIETH-CENTURY AMERICAN ETHNIC LITERATURE. New York: Cambria, 2012. Print.

5. Elliott P. Schuman. A psychoanalytic study of Hansel and Gretel. Journal of Contemporary Psychotherapy Volume 4, Issue 2, pp $121-125$

6. "Grimm and Grimmer: "Hansel and Gretel" and Fairy-Tale Nationalism" by Harshbarger, Scott - Style, Vol. 47, Issue 4, Winter 2013 Online Research Library:

7. Keeling, Kara K. and Scott T. Pollard. “Food in Children's Literature.”Critical Approaches to Food in Children's Literature. London: Routledge, 2009. 3-20. Print. Children's Literature and Culture. Ser.

8. Fahmi, M. E. (2016). Helen Recorvits's and Gabi Swiatkowska's My Name is Yoon (2003): A Postcolonial Picture Book of Asian American Child's Journey Into Assimilation and Heterogeneity.

9. Mannur, Anita. “Food Matters.”Culinary Fictions: Food in South Asian Diasporic Culture. Philadelphia: Temple UP, 2010. 1-26. Print.

10. Palmer, Alan. Fictional Minds: Frontiers of Narrative. Ed. David Herman. Nebraska: Nebraska UP, 2004. Print. Fictional Minds.

11. Smith, John L. The Psychology of Food and Eating: A Fresh Approach to Theory and Method. Hampshire: Palgrave, 2002. Print.

12. The Visit.(2015) Dir. Night Shyamalan. Blinding Edge Pictures, Video cassette.

13. Xu, Wenying. Eating Identities: Reading Food in Asian American Literature. Honolulu: Hawaii UP, 2008. 
